

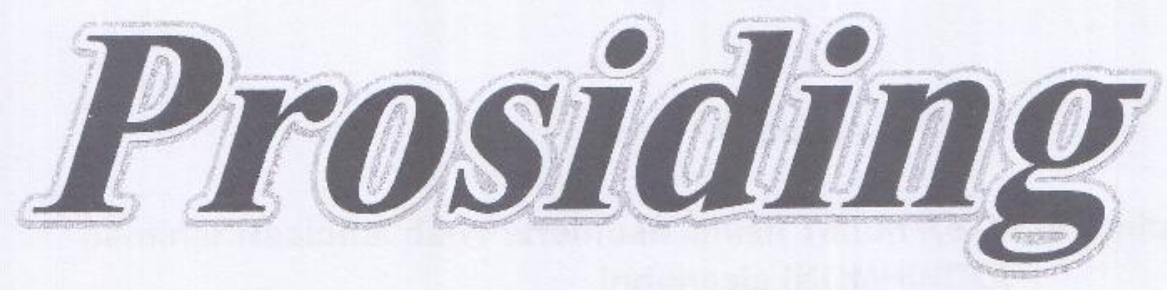

\section{Seminar Nasional dan Pertemuan Ilmiah Tahunan ke - 2 KOMHINDO}

Pengelolaan Hutan Berbasis KPH untuk Keberlanjutan Produksi, Ekologi dan Sosial Ekonomi Budaya Masyarakat

Diterbitkan Oleh :

LAMBUNG MANGKURAT Bekerjasama dengan UNIVERSITY PRESS
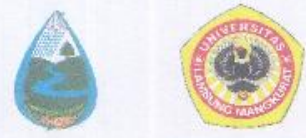

Banjarbaru - Loksado - Kalimantan Selatan 08 - 09 Oktober 2016 


\section{PENGELOLAAN HUTAN BERBASIS KPH UNTUK KEBERLANJUTAN PRODUKSI, EKOLOGI DAN SOSIAL EKONOMI BUDAYA MASYARAKAT}

\section{Prosiding}

Seminar Nasional dan Pertemuan IImiah Tahun Ke-2 Komunitas Manajemen Hutan Indonesia (KOMHINDO)

Banjarbaru, 08 - 09 Oktober 2016

\section{PENGELOLAAN HUTAN BERBASIS KPH UNTUK KEBERLANJUTAN PRODUKSI, EKOLOGI DAN SOSIAL EKONOMI BUDAYA MASYARAKAT}

\section{Prosiding}

Seminar Nasional dan Pertemuan llmiah Tahun Ke-2 Komunitas Manajemen Hutan Indonesia (KOMHINDO)

Banjarbaru, 08 - 09 Oktober 2016

Diterbitkan oleh:

Lambung Mangkurat University Press, 2016

d/a Pusat Pengelolaan Jurnal dan Penerbitan Unlam

Jl. H.Hasan Basry, Kayu Tangi, Banjarmasin 70123

Gedung Rektorat Unlam Lt 2

Telp/Faks. 0511-3305195

Hak cipta dilindungi oleh Undang-undang

Dilarang memperbanyak Buku ini sebagian atau seluruhnya, dalam bentuk dan cara apa pun, baik secara mekanik maupun elektronik, termasuk fotocopi, rekaman dan lain-lain tanpa izin tertulis dari penerbit

IX $-711 \mathrm{~h} 15,5 \times 23 \mathrm{~cm}$

Cetakan pertama, Desember 2016

Sampul dan Lay Out:

Editor:

Dr. Hafizianor, S. Hut, MP

Dr. Yusanto Nugroho, S. Hut, MP

Susilawati, S. Hut, MP

ISBN: 978-602-6483-08-9 


\section{LAPORAN KETUA PANITIA}

\section{Seminar Nasional dan Pertemuan IImiah Tahun Ke-2 Komunitas Manajemen Hutan Indonesia (KOMHINDO)}

\section{“PENGELOLAAN HUTAN BERBASIS KPH UNTUK KEBERLANJUTAN PRODUKSI, EKOLOGI DAN SOSIAL EKONOMI BUDAYA MASYARAKAT"}

Bismillahirrahmanirrahim,

Assalamu'alaikum Warahmatullahi Wa barakatuh, Yang terhormat:

- Rektor Universitas Lambung Mangkurat

- Bupati Hulu Sungai Selatan

- Dekan Fakultas Kehutanan Universitas Lambung Mangkurat

- Para Narasumber Prof.Dr.Ir.Didik Suhardjito,M.S, Prof.Ir.Udiansyah,Msi,PhD, Aji Sukmono, S. Hut, MP (Kepala KKPH Yogyakarta)

- Yang kami banggakan juga berhadir Guru Besar Fakultas Kehutanan Unlam Prof.Dr.Ir.Gt.M.Hatta (Mantan Menteri LH dan Menristek pada Kabinet Indonesia Bersatu II) dan Prof.Dr.Ir.M.Ruslan,MS (Mantan Rektor Unlam tahun 2010-2014)

- Para tamu undangan dan peserta seminar Komhindo

Hadirin yang saya hormati,

Kami selaku Ketua Panitia Seminar, menyampaikan puji syukur kepada Allah SWT, dimana kita dapat bersama-sama berkumpul dalam acara Seminar Nasional dan Pertemuan IImiah Ke-2 KOMHINDO. Selamat Datang di Fakultas Kehutanan Unlam yang di apit oleh 3 kota yaitu Banjarbaru kota idaman, Martapura kota Intan, Kota Serambi Mekah dan Kota Santri. Banjarmasin kota seribu sungai, kota Bumi Antasari. Besok di acara field trip kita akan bertemu dengan kota Kandangan dengan julukan Bumi Antaludin.

Tema Seminar Nasional dan Pertemuan IImiah Ke-2 Komunitas Manajemen Hutan Indonesia ini adalah"Pengelolaan Hutan Berbasis KPH Untuk Keberlanjutan Produksi, Ekologi Dan Sosial Ekonomi Budaya Masyarakat" dengan Tujuan Seminar adalah :

1. Mempublikasikan hasil-hasil penelitian ilmiah yang berkaitan dengan hutan dan keberlanjutan produknya dalam rangka pengelolaan hutan berbasis $\mathrm{KPH}$.

2. Membangun networking dan meningkatkan kerjasama antara para ilmuan/akademisi/peneliti, penyuluh, praktisi, dan birokrat untuk bersama-sama membumikan $\mathrm{KPH}$ agar konsep $\mathrm{KPH}$ dapat menjaga keberlanjutan produksi hutan, ekologi hutan, dan sosial ekonomi budaya masyarakat sekitar hutan.

Peserta seminar nasional KOMHINDO pada tahun ini berasal dari 16 Perguruan Tinggi dan 13 Balai Kehutanan/Dinas/KPH/Perusahaan sebagai pemakalah dengan 81 artikel ilmiah yang dibagi menjadi 4 (empat) tema seminar yaitu: Aspek Regulasi, Kebijakan, land tenurial dan Manajemen Hutan; Aspek Teknis Budidaya Pengelolaan Hhutan, Produksi Kayu dan Hasil Hutan Bukan Kayu; Aspek Ekologi dan Konservasi dan Aspek Sosial - Ekonomi Pengelolaan Hutan.

Sumber dana yang digunakan dalam pelaksanaan seminar ini berasal dari Universitas Lambung Mangkurat, Pemerintah Kabupaten Hulu Sungai Selatan dan Kontribusi dari para Perserta Seminar. Oleh karena itu kami menyampaikan terimakasih kepada Bapak Rektor Universitas Lambung Mangkurat dan Bupati Hulu sungai Selatan atas persetujuan yang diberikan. Demikian pula kepada Bapak Dekan Fakultas Kehutanan Unlam yang merupakan inisiator seminar dan pertemuan IImiah ini.

Demikian yang dapat saya sampaikan selaku Ketua Panitia Seminar dan Pertemuan IImiah Ke-2 KOMHINDO, dan selamat menjalankan seminar mudah-mudahan Allah SWT memudahkan setiap langkah kita. 


\section{SAMBUTAN REKTOR UNIVERSITAS LAMBUNG MANGKURAT*)}

Sambutan Rektor Universitas Lambung Mangkurat

Assalamu'alaikum wa rahmatullahi wa barakatuh

Yang saya hormati Bupati Hulu Sungai Selatan Provinsi Kal-Sel

Yang saya Hormati Dekan Fakultas Kehutanan Unlam

Yang saya Hormati Ketua Raki dan Kepala KKPH Yogyakarta, dan tamu undangan dari Perguruan Tinggi dan Litbang Kehutanan dari berbagai daerah di Indonesia serta Peserta Seminar KOMHINDO (Komunitas Manajemen Hutan Indonesia) yang berbahagia.

Hadirin yang saya hormati,

Seminar Komhindo dengan Tema "Pengelolaan Hutan Berbasis KPH Untuk Keberlanjutan Produksi, Ekologi Dan Sosial Ekonomi Budaya Masyarakat” merupakan sarana untuk memberikan sumbangan pengetahuan dalam mendorong keberlanjutan ekosistem hutan dan perbaikan dalam tata kelola hutan dengan berbagai model KPH guna mewujudkan kedaulatan ekonomi, politik, kepribadian dan kebudayaan bangsa. Berbagai model KPH dilahirkan seperti di Kabupaten Hulu Sungai Selatan dengan Model KPHL dan berbagai wilayah lain dengan model KPHP yang berbasis pada potensi tapak akan lebih menjamin keberlanjutan tata kelola hutan di Indonesia.

Saya mengucapkan terimakasih kepada Bupati Hulu Sungai Selatan atas kerjasamanya dalam Pelaksaan Seminar Nasional Komhindo ke-2 yang diselenggarakan oleh Fakultas Kehutanan Unlam Tahun 2016. Selain itu Universitas Lambung Mangkurat sering melakukan kerjasama dengan Kabupaten Hulu Sungai Selatan dalam bidang penelitian baik mahasiswa maupun dosen terutama dibidang lingkungan, Farmasi dimana Hutan Lindung Loksado menyimpan segudang tumbuhan obat tradisional maupun budaya adat Dayak yang masih lestari diwilayah KPHL model di Loksado Kabupaten Hulu Sungai Selatan.

Saya juga memberikan apresiasi terhadap Dekan Fakultas Kehutanan Unlam dan seluruh panitia yang telah bekerja keras dalam penyelenggaraan seminar Komhindo ini, yang telah dipersiapkan beberapa bulan yang lalu mudah-mudahan seminar ini berjalan dengan lancar, sesuai harapan termasuk kegiatan field trip tanggal 9 Oktober 2016 di KPHL Loksado Hulu Sungai Selatan.

Demikian, dari saya. Saya akhiri, wassalamu'alaikum wa rahmatullahi wa barakatuh.

*) Sambutan Rektor yang disampaikan oleh Wakil Rektor I, mewakili Rektor. 


\section{PRAKATA}

Pengelolaan hutan dengan konsep $\mathrm{KPH}$ diharapkan dapat menjamin kelestarian dan keberlanjutan ekosistem hutan dan bermanfaat sebesar-besarnya untuk dapat menunjang kedaulatan energi, pangan dan kesehatan bagi masyarakat. Oleh karena itu pengelolaan hutan dengan konsep $\mathrm{KPH}$ merupakan langkah yang signifikan menuju perbaikan tata kelola hutan untuk menuju Indonesia baru guna mewujudkan kedaulatan ekonomi, politik, kepribadian dan kebudayaan bangsa. Berbagai hasil-hasil riset dari seluruh tanah air yang disampaikan melalui kegiatan Seminar Nasional dan Pertemuan Ilmiah Komunitas Manajemen Hutan Indonesia (KOMHINDO) Ke-2 tahun 2016 dengan tema Pengelolaan Hutan Berbasis KPH untuk keberlanjutan produksi, ekologi, dan sosial ekonomi budaya masyarakat.

Hasil-hasil riset yang telah disampaikan dalam Seminar Nasional dan Pertemuan IImiah Komunitas Manajemen Hutan Indonesia (Komhindo) Ke-2 tahun 2016 tersebut diwujudkan dalam bentuk buku prosiding. Prosiding ini telah dikelompokkan berdasarkan masing-masing tema artikel. Tema artikel dalam prosiding ini meliputi; Aspek Regulasi, Kebijakan, Land Tenurial Dan Manajemen Hutan; Aspek Teknis Budidaya Pengelolaan Hutan, Produksi Kayu Dan Hasil Hutan Bukan Kayu; Aspek Ekologi Dan Konservasi Serta Aspek Sosial-Ekonomi Pengelolaan Hutan.

Jumlah keseluruhan artikel yang telah dipublikasikan dalam prosiding ini sebanyak 81 artikel. Banyaknya jumlah artikel yang masuk disebabkan oleh besarnya tingkat partisipasi para peneliti di seluruh tanah air untuk turut berkontribusi dalam pengelolaan hutan untuk keberlanjutan produksi, ekologi, dan sosial ekonomi budaya masyarakat. Berbagai sumbangan artikel dari para peneliti diseluruh tanah air maka editor mewakili tim menyampaikan terimakasih dan penghargaan yang sebesar-besarnya.

Akhirnya, kami menyadari walaupun seluruh artikel yang berhasil dimasukkan dalam prosiding ini telah melalui editor, namun mungkin terdapat kesalahan dan ketidaksempurnaan di dalamnya, oleh karena itu kami menyampaikan permohonan maaf yang sebesar-besarnya atas kesalahan cetak dalam prosiding ini. Kami berharap agar prosing ini menjadi salah satu alternative sumber referensi di bidang Kehutanan dan menjadi pionir bagi riset-riset baru di bidang pengelolaan hutan terutama dalam pengelolaan hutan berbasis $\mathrm{KPH}$.

Banjarbaru, Oktober 2016

Editor, 


\section{DAFTAR ISI}

Halaman

HALAMAN JUDUL

LAPORAN KETUA PANITIA ................................................................

SAMBUTAN REKTOR UNIVERSITAS LAMBUNG MANGKURAT..................... iv

PRAKATA

I. DAFTAR PEMAKALAH UMUM SEMINAR NASIONAL KOMHINDO 2016 TAHUN KE-2

II. FULL PAPER KOMISI

A. KOMISI A : ASPEK REGULASI, KEBIJAKAN, LAND TENURIAL DAN MANAJEMEN HUTAN

1. Ketahanan Daerah Aliran Sungai (DAS) Berbasis Kearifan Lokal (Studi Kasus di Sub-Sub DAS Lengkese, Sub DAS Lengkese DAS Jeneberang)

2. Skenario Luas Lahan Berhutan Untuk Optimalisasi Fungsi Ekonomi dan Ekologi Daerah Hulu DAS Tondano Sulawesi Utara

3. Konsistensi Regulasi Dalam Bidang Kehutanan Implikasinya Terhadap Tindak Pidana Kehutanan

4. Strategi Magement Regime (Rejim Pengelolaan) Dalam Pengelolaan Hutan Jati Bersama Masyarakat di Resort Polisi Hutan (RPH) Madampi Bagian Kesatuan Pengelolaan Hutan (BKPH) Muna Tengah

5. Dampak Kebijakan Sertifikasi Terhadap Perkembangan Hutan Rakyat di Kabupaten Pacitan

6. Prospek Ekonomi Pembangunan KPH (Kesatuan Pengelolaan Hutan) Sebagai Entitas Bisnis Melalui Strategi Diversifikasi Produk dan Jasa (Teori, Implementasi, Usulan Kebijakan)

7. Kajian Keberlanjutan Pengelolaan Hutan Mangrove Di Mangrove Center Graha Indah (MCGI) Kota Balikpapan Provinsi Kalimantan Timur

8. Dinamika Menuju Kesatuan Pengelolaan Hutan Produksi (KPHP) Hutan Pendidikan Fakultas Kehutanan Universitas Mulawarman "Sebuah Harapan dan Tantangan.

9. Strategi Pengelolaan Jasa Lingkungan Wisata Alam Arung Jeram Di Kawasan Kesatuan Pengelolaan Hutan Telake Kabupaten Paser Provinsi Kalimantan Timur

10. Strategi Pengembangan KPHP Bongan Menuju Pemanfaatan Hutan Lestari.....

11. Penataan Batas Kawasan Hutan di KPHP Model Banjar 
12. Besaran Nilai Produk Hutan sebagai Barometer Pembentukan Hutan Lestari.

13. Studi Perbandingan Penataan Hutan dengan Pola Ruang Hutan Berbasis Boxgrid dan Berbasis Daerah Aliran Sungai dalam Rangka Pengelolaan Hutan Lestari...

14. Perkembangan Pembangunan KPH di Sulawesi Selatan .................
15. Kajian Kebijakan Pengelolaan Hutan Konservasi Berbasis Masyarakat (Studi Kasus SM Kuala Lupak dan Pulau Kaget Kalimantan Selatan)

B. KOMISI B : ASPEK TEKNIS BUDIDAYA PENGELOLAAN HUTAN, PRODUKSI KAYU DAN HASIL HUTAN BUKAN KAYU

1. Pengaruh Pola Tanam Campuran terhadap Pertumbuhan Tanaman Mangium, Mahoni dan Sengon di Lahan Alang-Alang

2. Analisa Resiko Organisme Pengganggu Tumbuhan (AROPT) Untuk Importasi Fagus Sylvatica Dari Switzerland ke Dalam Wilayah Indonesia

3. Uji Coba Penanaman Nyawai (Ficus variegata Blume) di $\mathrm{KPH}$ Yogyakarta

4. Pembibitan Beberapa Varietas Murbei (Morus sp) Untuk Mendukung Persuteraan Alam di Kabupaten Soppeng ....

5. Kebun Benih Uji Keturunan Bitti (Vitex cofassus) Untuk Memenuhi Kebutuhan Masyarakat di Kabupaten Enrekang

6. Pengaruh Kompos Dan Mulsa Jerami Terhadap Pertumbuhan Tanaman Mahoni (Swieteniamacrophyllaking) Di Mengkendek, Kab. Tanatoraja

7. Respon Pertumbuhan Bibit Trembesi (Samanea Saman) Terhadap Pemberian Pupuk NPK Di Persemaian

8. Pertumbuhan Mahoni Pada Area Bekas Stockpile PT Jorong Barutama Grestin dengan Pemberian Pupuk Organik

9. Pertumbuhan Tanaman Meranti Merah (Shorea pauciflora King.) Umur 36 Bulan pada Berbagai Ukuran Rumpang di KHDTK Kintap ..

10. Model Revegetasi Lahan Bekas Tambang Batubara

11. Evaluasi Teknik Silvikultur, Pertumbuhan Dan Hasil Tegakan Hutan Tanaman Sungkai Di Kabupaten Barito Utara Kalimantan Tengah....

12. Kualitas Papan Partikel Berbahan Baku Limbah Pengolahan Kayu dan Limbah Tanaman Pertanian.

13. Limbah Industri Kayu Lapis dan Limbah Kayu HTI Untuk Pembuatan Briket Arang.

14. Prestasi Kerja dan Pengorganisasian Pemanenan Daun Kayu Putih di KPH Yogyakarta

15. Kemampuan Daya Serap Arang Aktif Kayu Galam (Melaleuca Leucadendron Linn) Terhadap Benzena dan lodium

16. Hubungan Luas Sampel Eceng Gondok (Eichornia crassipes) dan Rendemen Pada Pengolahan Tas di Kecamatan Candi Laras Selatan Kabupaten Tapin C. 
17. Kajian Senyawa Kimia Gula Cair (Liquid Sugar) dalam Rangka Peningkatan Kualitas dan Inovasi Produk Gula Banua .

18. Pengaruh Jarak Tanam Terhadap Pertumbuhan Tanaman Nyawai (Ficus Variegata Blum.) Umur 4 Tahun di KHDTK Riam Kiwa

19. Aplikasi Pupuk Bioorganik Cair dan Mulsa Pada Peningkatan Pertumbuhan Tanaman Aren (Arenga pinnata Merr.)

20. Studi Fitokimia Empat Jenis Tumuhan Rawa Kabupaten Barito Kuala

21. Budidaya Lebah Madu Kelulut (Apis Trigona) di Desa Karang Taruna

22. Pengaruh Kalsium (Ca) Terhadap Pertumbuhan tanaman Jati (Tectona grandis L.F) di Tropika Basah

C. KOMISI C : ASPEK EKOLOGI DAN KONSERVASI

1. Pemetaan Sebaran Hotspot di Kabupaten Banjar Kalimantan Selatan

2. Konservasi Biodiversitas Burung Air (Studi Kasus di Divisi I PT Gunung Madu Plantations Kabupaten Lampung Tengah Provinsi Lampung)

3. Sebaran Dan Karaktersitik Sarang Burung Elang Sulawesi di Hutan Pendidikan UNHAS

4. Perilaku Harian Primata (Hylobates syndactylus, Macaca fascicularis, Presbytis melalophos) di Pusat Primata Schmutzer Taman Margasatwa Ragunan Jakarta

5. Pemenuhan Kebutuhan Pakan Rusa melalui Drop In di Penangkaran Rusa PT GMP (Studi di GMP Lampung Tengah).

6. Perilaku Harian Great Apes (Gorilla Gorilla, Pantroglodytes Blumenbach, Pongo Pygmaeus) di Pusat Primata Schmutzer Taman Margasatwa Ragunan Jakarta Selatan

7. Analisis Potensi Erosi Menggunakan Sistem Informasi Geografi di DAS Olonjonge Wilayah KPH Dolago Tanggunung

8. Potensi Jumpun Pembelon Sebagai Ekowisata Berbasis Kelestarian Ekosistem Gambut

9. Partisi Curah Hujan Pada Berbagai Tegakan di Daerah Tangkapan Air Binang Jajang

10. Konservasi S. belangeran dari Hutan Kerangas Sebagai Bahan Obat Alami

11. Komposisi Vegetasi Habitat Jamblang Pada Hutan Rakyat Desa Wonosadi Kecamatan Pajangan Kabupaten Bantul Yogyakarta

12. Kuantitas dan Kualitas Air Untuk Penentuan Daya Dukung DAS Tabunio Kabupaten Tanah Laut.

13. Arahan Pemanfaatan Lahan Berdasarkan Kemampuan Lahan di Sub DAS Kusambi Kabupaten Tanah Bumbu Kalimantan Selatan

14. Karakterisasi DAS Satui Untuk Penentuan Kerawanan Banjir di Kabupaten Tanah Bumbu

15. Risiko Banjir dan Upaya Pengendaliannya Di Sub DAS Martapura Kabupaten Banjar

16. Potensi Nyawai (Ficus variegeta Blume) Sebagai Tanaman Obat ......

17. Etnobotani Tumbuhan Berkhasiat Obat di Kecamatan Marabahan dan Tabukan Kabupaten Barito Kuala Propinsi Kalimantan Selatan 
18. Keanekaragaman Jenis Buah Lokal di Kabupaten Sintang Kalimantan Barat

19. Keanekaragaman Jenis Pohon Riparian Pada Sub Das Nanga Silat Kecamatan Silat Hilir Kabupaten Kapuas Hulu

20. Potensi Ekowisata Pantai Pagatan Di Kabupaten Tanah Bumbu Kalimantan Selatan.

21. Kajian Kekritisan Lahan dan Aspek Sosial Ekonomi Sebagai Arahan Penentuan Urutan Prioritas Rehabilitasi Hutan dan Lahan Di Sub-Sub DAS Amandit Kalimantan Selatan

22. Efektivitas Stik Jarum dalam Pemadaman Kebakaran Lahan Gambut

23. Kajian Biomassa dan Kandungan Karbon Pada Hutan Rawa Galam (Melaleuca cajuputi)

24. Penyusunan Persyaratan Tumbuh Jenis Ulin (Eusideroxylon zwageri t. \& b.) dengan Penggunaan Sistem Informasi Geografis (SIG)

D. KOMISI D : ASPEK SOSIAL-EKONOMI PENGELOLAAN HUTAN

1. Kajian Pemanfaatan Hutan Daerah Panyangga Untuk Ketahanan Pangan Masyarakat Sekitar Hutan Studi Kasus di Enclave Lindu Taman Nasional Lore Lindu

2. Analisis Tekanan Penduduk Dan Dukungan Aspek Sosial Ekonomi Masyarakat dalam Rangka Perencanaan RHL di Sub Amandit

3. Keterkaitan Kearifan Lokal Masyarakat Dayak Taboyan Dalam Pelestarian Hutan Lindung Lampeong-Gunung Lumut Kabupaten Barito Utara

4. Studi Potensi HHBK di Hutan Pendidikan UM Palangkaraya

5. Model Perlindungan Hutan dengan Pendekatan Pemanfaatan HHBK Bagi Masyarakat Kawasan Hutan Pendidikan UM Palangkaraya........

6. Strategic Business Unit sebagai Suatu Model Pelibatan Masyarakat dalam Pengembangan Konsep KPH.

7. Analisis Biaya Penanaman dan Pendapatan pada Pembangunan Model Unit Manajemen Hutan Meranti (Shorea. Spp) PT Inhutani II Kotabaru

8. Tumbuhan Hutan Berbahaya yang Berpotensi Menggangu Kesehatan

9. Insentif Finansial Pengelolaan Hutan Alam Produksi Lestari Dari Skema Perdagangan Karbon

10. Analisis Kelayakan Usaha Pemanfaatan Bambu (Studi Kasus di Desa Panggungan Kecamatan Loksado Kabupaten Hulu Sungai Selatan)..

11. Pengembangan Sistem Pengelolaan Agroforestri Lahan Basah Berbasis Pengetahuan dan Teknologi Ekologi Lokal

12. Pengetahuan Masyarakat Tentang KPHL Rinjani Barat dan Pengelolaannya

13. Demplot Agroforestry Bambu Media Belajar Bersama Masyarakat.....

14. Kondisi Kelembagaan Petani Hutan Untuk Mendukung Perekonomian (Kasus Desa Labuhan Badas, Kabupaten Sumbawa, NTB)

15. Pengetahuan Petani Hutan Rakyat mengenai Peraturan Peredaran Kayu Rakyat di Ciamis, Tasikmalaya dan Sukabumi 
16. Pengetahuan Masyarakat Petani Dalam Pemanfaatan Tanaman Hutan Jenis Obat (Syzygium cumini Linn)

17. Penerapan Konsep-Konsep Hukum Adat Dalam Pengelolaan Hutan (Studi Suku Dayak Halong di Kab. Balangan)

18. Kelestarian Praktek Agroforestri Lokal Pada Masyarakat Karo di Sekitar Taman Wisata Alam Sibolangit Provinsi Sumatera Utara

19. Pengetahuan Penyuluh Kehutanan Sebagai Pelaku Pemberdayaan Masyarakat Dalam Pengelolaan Hutan Rawa (Studi Di Kawasan Hutan Konservasi Suaka Margasatwa Kuala Lupak)

20. Kajian Sistem dan Pola Pemanenan Hutan Rakyat di Daerah Tangkapan Hujan DAS Jeneberang. 


\title{
POTENSI JUMPUN PEMBELON SEBAGAI EKOWISATA BERBASIS KELESTARIAN EKOSISTEM GAMBUT
}

\author{
EPI SULASTRI ${ }^{1}$, TEGUH PRIBADI $^{2, \varnothing}$, ASRO' $^{\prime}$ LAELANI INDRAYANTI ${ }^{3,}$ DEDY NORSANDI ${ }^{1}$ \\ ${ }^{1}$ Program Studi Pendidikan Geografi, Fakultas Keguruan dan Ilmu Pendidikan, Universitas PGRI \\ Palangka Raya. Jl. Hiu Putih-Tjilik Riwut km 7 Palangka Raya, Kalimantan Tengah 73113, \\ ${ }^{2}$ Program Studi Kehutanan, Fakultas Pertanian, Universitas PGRI Palangka Raya, JI. Hiu Putih- \\ Tjilik Riwut km 7 Palangka Raya, Kalimantan Tengah 73113. `email: tgpribadi@gmail.com. \\ ${ }^{3}$ Program Studi Agribisnis, Fakultas Pertanian, Universitas PGRI Palangka Raya, Jl. Hiu Putih- \\ Tjilik Riwut km 7, Palangka Raya, Kalimantan Tengah 73113.
}

\begin{abstract}
ABSTRAK
Kepariwisataan alam berbasiskan kelestarian ekologi dan sosial saat ini semakin luas dikenal sebagai salah satu daya tarik ekonomi yang menguntungkan dan terus dipromosikan secara gencar dalam upaya konservasi alam. Ekowisata Jumpun Pembelom (EJP) merupakan salah satu destinasi wisata baru berupa kawasan ekosistem gambut yang masih alami. EJP berupa kawasan konservasi yang dikelola secara privat dan menjadi salah satu percontohan pengelolaan lahan gambut di Palangka Raya. Potensi EJP diukur untuk pengembangan ekowisata berkelanjutan. Sigi tentang karakteristik pengujung dilakukan untuk mengukur demografi pengunjung. Sedangkan, penilaian obyek dan daya tarik wisata alam (ODTWA) diterapkan untuk mengukur potensi pengembangan ekowisata. Pengunjung EJP umumnya adalah pengunjung dengan tujuan khusus dengan misi pendidikan dan konservasi sebagai motivasi utamanya. Meskipun, memiliki potensi daya tarik wisata yang rendah. EJP sebagai ekowisata berbasis kelestarian ekosistem gambut layak dikembangkan lebih lanjut. Promosi dan penambahan sarana dan prasarana wisata alam dapat ditambahkan untuk meningkatkan kunjungan wisatawan.
\end{abstract}

Kata kunci: ekowisata, ekosistem gambut, Jumpun Pembelom, ODTWA

\section{LATAR BELAKANG}

Indonesia yang terdiri dari daratan dan lautan membentuk kekayaan tumbuhan dan hewan yang terbesar di dunia. Lingkungan yang memiliki iklim tropis dengan posisi geografi yang melingkari di antara Asia dan australia telah menghasilkan kawasan fauna dan flora yang tidak dapat dibandingkan dengan negara manapun di dunia. Di samping itu, Indonesia juga mempunyai keanekaragaman budaya, agama, dan etnik yang tersebar di pantai, savana, pengunungan, dan desa-desa tradisional. Keanekaragaman jenis serta kekayaan flora dan fauna yang dimiliki Indonesia membuat Indonesia mempunyai kedudukan yang terhormat di dunia (Supriatna, 2008).

Indonesia memiliki keragaman lanskap yang tinggi sebagai akibat proses geomorfik. Lansakap tersebut memiliki ciri dan corak yang unik sebagai akibat perbedaan bahan pembentuk, proses, dan waktu pembentukan (Afra et al., 2008). Keragaman inilah yang menjadi daya tarik wisata sehingga pengunjung atau wisatawan melakuan perjalanan wisata ke daerahdaerah yang unik dan indah tersebut. 
Lebih lanjut, Pariwisata berbasiskan kelestarian ekologi dan sosial (ekowisata) saat ini semakin luas dikenal sebagai salah satu daya tarik ekonomi yang menguntungkan dan terus dipromosikan secara gencar dalam upaya konservasi ekosistem tropika. Namun, banyak daerah yang memiliki kondisi alam yang asli dan budaya lokal yang sangat potensial untuk kegiatan wisata telah rusak karena ketidaktahuan dalam pemanfaatan, perencanaan dan pengelolaannya (Purwanto, 2014). Di sisi lain, peningkatan permintaan wisata ke daerah-daerah yang alami akan berdampak pada penurunan daya dukung kawasan yang alami baik secara kualitas maupun kuantitasnya.

Ekowisata secara konseptual dapat didefinisikan sebagai suatu konsep pengembangan pariwisata berkelanjutan yang bertujuan untuk mendukung upaya-upaya pelestarian lingkungan dan meningkatkan partisipasi masyarakat dalam pengelolaan sehingga memberikan manfaat ekonomi kepada masyarakat setempat. Sementara itu, ekowisata ditinjau dari segi pengelolaanya dapat didefinisikan sebagai penyelenggaraan kegiatan wisata yang bertanggung jawab di tempat-tempat alami yang dibuat berdasarkan kaidah alam dan berkelanjutan secara ekonomi dalam upaya mendukung pelestarian lingkungan dan meningkatkan kesejahteraan masyarakat setempat (Supriatna, 2008).

Ekowisata tidak hanya diyakini dapat mendorong pertumbuhan ekonomi secara lokal maupun regional untuk peningkatan kesejahteran masyarakat tetapi juga kelestarian sumber daya alam dan keanekaragaman hayati sebagai obyek dan daya tarik wisata. Ekowisata mengutamakan upaya konservasi sumber daya alam, pengembangan ekonomi dan pemberdayaan masyarakat yang dilakukan secara baik, benar, bertanggung jawab serta berkelanjutan. Pengembangan ekowisata harus menggunakan kaidah-kaidah berkelanjutan yang terdiri dari: 1) pembangkitan peluang peningkatan ekonomi bagi masyarakat lokal; 2) pemberian perlindungan kawasan konservasi dan kawasan lindung; dan 3) pembukaan ruang untuk memberikan penghormatan hak atas sumber daya alam, baik bersifat perorangan maupun kelompok. Orientasi jangka panjang dari pengembangan ekowisata adalah terciptanya keuntungan dan kesetaraan kepentingan sosial, ekonomi, dan lingkungan (Purwanto, 2014).

Kota Palangka Raya, dataran rendah yang dibelah oleh Sungai Kahayan dan dikelilingi lahan gambut, membentuk lanskap dan pemandangan alam yang unik. Kondisi geografis ini menjadikan Palangka Raya memiliki potensi wisata alam yang beragam (Ningsih, 2014). Kondisi ekosistem gambut yang masih alami menjadi destinasi baru kepariwisataan alam di Palangka Raya. Salah satunya adalah Jumpun Pembelom (JP) yang merupakan kawasan privat yang dikelola untuk pengembangan ekowisata. Namun demikian, potensi ekowisata yang ada di JP 
belum dikaji secara rinci. Oleh karena itu perlu dilakukan analisis yang berusaha untuk mendeskripsikan karakteristik pengunjung EJP dan mengukur potensi ekowisata JP.

\section{METODE PENELITIAN}

Lokasi Studi. Ekowisata Jumpun Pembelom (EJP) dipilih sebagai lokasi sigi penelitian dengan pertimbangan subtantif sebagai berikut: 1) EJP merupakan ekosistem hutan gambut sekunder yang dikelola dengan baik secara privat; dan 2) kawasan ini dikembangkan sebagai pusat pendidikan lingkungan hidup, pelestarian keanekaragaman tanaman langka, dan demplot pengelolaan lahan gambut swadaya; dan 3) EJP berada dekat dengan pusat Kota Palangka Raya. EJP terletak di Jalan Trans Kalimantan kilometer 30,5; Desa Tumbang Nusa, Kecamatan Jabiren Raya, Kabupaten Pulang Pisau dengan koordinat 02 21,098' LS \& $114^{\circ} 05,623^{\prime}$ BT (Gambar 1).

Sampel Studi. Populasi pengunjung EJP adalah seluruh pengunjung EJP dalam kurun waktu dua bulan terakhir (Februari - Maret 2016). Teknik sampling insidental digunakan untuk memilih pengunjung yang akan dijadikan sebagai responden. Jumlah sampel studi dihitung dengan persamaan Slovin yang dikutip oleh Sarjono \& Julianita (2011), sebagai berikut:

$$
n=\frac{N}{N d^{2}+1}
$$

Keterangan:

$n=$ jumlah sampel

$N=$ jumlah pengunjung EJP dari bulan Februari sampai Maret 2016 (71 pengunjung)

$d=$ batas maksimum kesalahan yang masih bisa diterima dengan asumsi $5 \%(0,05)$

$$
\begin{gathered}
n=\frac{71}{71(0,05)^{2}+1} \\
n=60,29 \approx 60
\end{gathered}
$$

Pengumpulan Data. Data primer diperoleh dari penyebaran angket yang kembangkan oleh Hastari (2005) dengan beberapa modifikasi digunakan untuk mengungkap karakteristik pengunjung EJP. Kemudian penilaian potensi ekowisata EJP diperoleh dari lembar pengamatan untuk menilai potensi obyek daya tarik wisata alam (ODTWA) yang disusun oleh Direktorat Jenderal Perlindungan Hutan dan Konservasi Alam (Ditjen PHKA) (2003) yang dikutip oleh Purwanto (2014). Data primer yang dikoleksi kemudian didukung dengan pendokumentasian yang terkait dengan EJP. Adapun data sekunder diperoleh dari pengelola EJP, instansi teknis terkait seperti Badan Pusat Statistik (BPS) dan Dinas Pariwisata Provinsi Kalimantan Tengah, ataupun sumber pendukung penting lainnya.

Analisis Data. Karakteristik pengunjung, persepsi dan motivasi pengunjung EJP diukur menggunakan statistika deskriptif. Adapaun potensi ekowisata dihitung dengan metode penskoran dan pembobotan terhadap indikator-indikator yang digunakan untuk mendapatkan 
penilaian kemudian direkapitulasi. Hasil rekapitulasi penilaian selanjutnya dapat digunakan untuk menentukan unsur-unsur dan sub-subunsur yang ada telah mencapai skor maksimal atau perlu ditingkatkan kembali. Hasil ini dapat digunakan sebagai bahan rekomendasi dalam pengelolaan obyek dan daya tarik wisata (Purwanto, 2014).

HASIL

Karakteristik pengunjung ditunjukan pada Tabel 1. Pengunjung EJP didominasi oleh kaum perempuan ( $>50 \%$ ) dan lebih dari tigaperempat pengunjung EJP memiliki status belum menikah. Mayoritas pengunjung EJP adalah dewasa muda dengan usia 21-30 tahun ( $>50 \%)$. Pengunjung EJP pada umumnya merupakan mahasiswa yang baru selesai dari pendidikan lanjutan tingkat atas ( $>70 \%)$. Pengunjung dengan tingkat pendidikan sarjana menempati porsi sebanyak $30 \%$ dari total pengunjung EJP. Umumnya mereka adalah mahasiswa $(>70 \%)$ yang lebih dari separohnya belum memiliki pendapatan tetap sendiri dan berpendapatan kurang dari satu juta rupiah. Selama kurun waktu tersebut, EJP hanya dikunjungi oleh wisatawan domestik.

Pengunjung EJP dilakukan secara berombongan (>90\%) dengan lama kunjungan berkisar dua sampai empat jam. Umumnya mereka berkunjung ke EJP untuk kali pertama. Bentuk kunjungan secara rombongan menyebabkan mereka tidak melakukan pengeluaran (>50\%) selama di EJP. Kurang dari seperempat pengunjung yang melakukan belanja di EJP < Rp. 200.000 (>25\%). Informasi tentang EJP didominasi dari informasi yang bersumber dari teman/kolega (>50\%). Posisi kedua, informasi tentang EJP diperoleh dari sekolah atau universitas (>10\%). Hal ini dimungkinkan karena kunjungan ke EJP biasanya terkait dengan kegiatan praktikum ataupun hal-hal yang berhubungan dengan pendidikan lingkungan hidup.

Secara umum EJP termasuk dalam kriteria sedang dan memiliki potensi untuk dikembangkan sebagai destinasi baru ekowisata di Palangka Raya (Tabel 3). Meskipun memiliki nilai yang rendah untuk daya tarik obyek wisata. Namun, aksesibilitas, akomodasi, ketersediaan air, hubungan dengan obyek wisata di sekitarnya, daya dukung kawasan, dan pangsa pasar menjadi komponen-komponen keunggulan EJP untuk dikembangkan menjadi destinasi baru ekowisata di Palangka Raya. Komponen-komponen yang harus dikembangkan lebih lanjut di EJP, selain daya tarik obyek wisata adalah elemen institusi, potensi pasar, dan keamanan.

\section{PEMBAHASAN}

EJP saat penelitian ini dilakukan didominasi oleh pengunjung berjenis kelamin perempuan. Meskipun hasil ini berbeda dibandingkan dengan penelitian sejenis (Hastari, 2005; Deni, 2010; Purnomo, 2013; Utari, 2014). Namun, secara umum laki-laki dan perempuan memiliki kebutuhan berwisata yang sama (Pramono \& Kunarso, 2008). Lebih lanjut, Pengunjung EJP didominasi oleh wisatawan yang berusia muda (21-30 tahun). Hal ini sesuai pendapat 
Purnomo (2013) yang menyatakan bahwa pengunjung wisata alam umumnya didominasi oleh remaja dewasa. Kunjungan wisatawan muda ke destinasi wisata alam dalam rangka berpetualang, mencari tantangan, motivasi fisik, serta alasan pendidikan dan penelitian. Di samping itu, keberadaan destinasi wisata baru menjadi alasan wisatawan muda berkunjung. Keberadaan yang dekat dengan Kota Palangka Raya menjadi pertimbangan lain dalam memilih EJP sebagai destinasi. Wisatawan cenderung melakukan perjalan wisata pada destinasidestinasi wisata terdekat dengan aksesibilitas mudah.

Adapun pengunjung EJP umumnya adalah pelajar/mahasiswa. Hasil sigi ini sejalan dengan sigi yang dilakukan di Arboretum Nyaru Menteng (Hastari, 2005), dan Pulau Sempu (Purnomo, 2013), Kebun Raya Cibodas (Utari, 2014). yang menyatakan bahwa pengunjung di kedua destinasi didominasi oleh pelajar/mahasiswa. Mereka melakukan kunjungan secara berombongan. Hal ini sesuai dengan pendapat Hastari (2005) dan Purnomo (2013) yang menyatakan bahwa bentuk kunjungan yang umum pada destinasi wisata alam adalah kedatangan berombongan. Kunjungan berombongan yang dilakukan oleh wisatawan muda berstatus pelajar/mahasiswa dilakukan dalam rangka mengekplorasi diri dengan melakukan perjalanan di destinasi wisata alam (Sari et al., 2015).

Pendidikan yang tinggi meningkatkan pemahaman mereka tentang konservasi sehingga mereka berminat untuk menikmati kepariwisataan alam (Purnomo, 2013). Hal ini didukung dengan fakta di lapangan bahwa mereka melakukan kunjungan untuk kali pertama dalam rangka perkuliahan dan kegiatan konservasi. Kegiatan ekowisata utamanya diperuntukan untuk kegiatan penelitian, pendidikan, konservasi, serta penjelajahan dan petualangan (Kurniawati, 2012).

Wisatawan muda umumnya merupakan wisatawan yang tidak loyal dan memiliki rasa penasaran kepada sesuatu yang baru. Hal ini dibuktikan dengan kunjungan mereka ke EJP didominasi oleh pengunjung dengan status kunjungan pertama kali. Informasi yang diperoleh hanya dari teman/kolega semakin memperkuat dugaan ini.

Ekowisata Jumpun Pembelom (EJP) memiliki ekosistem gambut yang masih alami. Di samping itu, eksesibilitas yang tinggi, keberadaan akomodasi pendukung kegiatan wisata yang lengkap, hubungan dengan obyek wisata di sekitarnya yang erat dan beragam, daya dukung kawasan yang masih baik, dan ketersediaan air bersih yang memadai menjadi daya faktor-faktor pendukung EJP untuk dikembangkan lebih lanjut. Meskipun daya tarik obyek wisatanya rendah tetapi kealamian ekosistemnya dapat menjadi daya tarik EJP. (Kurniawati, 2012) mengungkap bahwa tingkat kealamian ekosistem gambut merupakan salah satu daya tarik pengunjung untuk berwisata di Ekowisata Gambut Baning di Sintang. 
Secara umum, suatu destinasi wisata menarik untuk dikunjungi oleh wisatawan karena: 1) letaknya dekat; 2) mudah dijangkau dan nyaman; 3) memiliki atraksi yang menarik baik berupa satwa liar ataupun kekhasan kawasan tersebut; 4) kemudahan untuk melihat atraksi tersebut; 5) memiliki beberapa kesitimewaan yang berbeda; 6) memiliki budaya yang menarik; 7) penyajian atraksi yang unik; 8) memiliki obyek daya tarik wisata yang beragam; 9) cukup dekat dengan destinasi wisata lain yang menarik bagi wisatawan sehingga menjamin kegiatan peket wisata; 10) memiliki pemandangan yang sangat indah; dan 11) ketersedian makan dan akomodasi lain (Hastari, 2005). Lebih lanjut, pengembangan kepariwisataan alam harus mempertimbangkan faktor-faktor seperti daya tarik obyek wisata, transportasi, akomodasi, fasilitas penampung, dan infrastuktur (Effendi \& Sujali, 1989).

Komponen daya tarik wisata yang rendah dari EJP dapat ditingkatkan dengan penambahan fasilitas wisata alam di sana. Fasiltas-fasiltas tersebut antara lain: 1) titian (boardwalk) yang dilengkapi dengan fasilitas interpretasi, seperti papan intepretasi, papan penunjuk arah, dan naungan/gazebo (Kurniawati, 2012; Sari et al., 2015); 2) Pembuatan menara pengamatan burung (Sari et al., 2015); 3) fasilitas lain seperti: bangunan pusat informasi, persemaian tanaman hutan gambut, kios cinderamata, dan kios makanan (Kurniawati, 2012); 4) kegiatan outbond (Deni, 2010); 5) fotografi (Purnomo, 2013); 6) pemandu wisata (Kurniawati, 2012; Sari et al., 2015); 7) paket pembelajaran lingkungan hidup yang menarik (Afra et al., 2008; Purnomo, 2013), khususnya pengetahuan tentang ekosistem gambut; 8) fasilitas toilet dan tempat ibadah (Afra et al., 2008; Deni, 2010).

Elemen institusi EJP yang rendah dapat dilakukan dengan pembangunan jejaring kerjasama yang melibatkan semau pemangku kepentingan EJP. Pelaku kepentingan yang dapat dilibatkan dalam pengembangan EJP antara lain: seperti ekowisatawan, masyarakat setempat, pelaku usaha, lembaga swadaya masyarakat, dan pemerintah (Purnomo, 2013). Sedangkan potensi pasar yang rendah dapat dioptimalkan dengan peningkatan promosi tentang EJP dan kerjasama para pemangku kepenitingan. Perlindungan dan penjagaan kawasan dapat dilakukan untuk meningkatkan keamanan kawasan dari bahaya kebakaran lahan. Potensi keamanan terbesar dari EJP adalah resiko kebakaran lahan yang seringkali terjadi. Penerapan teknologi kanal sekat dan sumur bor selain untuk perlindungan kawasan juga dapat dijadikan sebagai wahana edukasi kepada ekowisatawan yang berkunjung ke EJP. 


\section{SIMPULAN}

Pengunjung EJP umumnya adalah pengunjung khusus dengan tujuan pendidikan lingkungan hidup seperti pelajar atau mahasiswa. Mereka melakukan kunjungan secara berombongan dengan durasi kurang dari empat jam. Informasi tentang EJP diperoleh dari teman/kolega dan sekolah/kampus. EJP memiliki potensi untuk dikembangkan menjadi destinasi baru ekowisata di Palangka Raya. Peningkatan daya tarik wisata dapat dilakukan dengan melakukan penambahan sarana dan prasarana obyek wisata alam. Di samping itu, pengelola EJP melakukan promosi yang lebih intensif tentang daya tarik EJP.

\section{DAFTAR PUSTAKA}

Afra, D., Makalew, N., Damayanti, V.D., Hadi, A.A.. 2008. Rencana Penataan Lansakap Gunung Kapur Cibadak untuk Ekowisata di Kecamatan Ciampea Kabupaten Bogor. Jurnal IImu Pertanian Indonesia. Vol. 13 (3): 182-193.

Deni. 2010. Kajian Awal terhadap Potensi Taman Buru Gunung Masigit Kareumbi Jawa Barat untuk Pengembangan Ekowisata. Jurnal IImu Kehutanan. Vol. 4 (1): 1-11.

Direktorat Jenderal Perlindungan Hutan dan Konservasi Alam (Ditjen PHKA). 2003. Pedoman Analisis Daerah Operasi Obyek dan Daya Tarik Wisata. Ditjen PHKA, Bogor.

Effendi, T.N., dan Sujali. 1989. Pengembangan Kepariwisataan: Sebuah Pendekatan Geografi. Majalah Geografi Indonesia. Vol. 2 (3): 1-9.

Hastari, B.. 2005. Karakteristik Obyek Wisata dan Persepsi Masyarakat sebagai Dasar dalam Pengembangan Wisata Alam Studi Kasus: Arboretum Nyaru Menteng Palangka Raya. [Tesis]. SPS IPB, Bogor.

Kurniawati, H.. 2012. Perencanaan Lanskap Kawasan Ekowisata gambut Baning di Kota Sintang Kalimantan Barat. [Tesis]. SPS IPB, Bogor.

Ningsih, L.. Analisis Pemasaran Wisata di Kota Palangka Raya. Jurnal Sains Manajemen. Vol 3 (1): 45-57.

Pramono, B.T., dan Kunarso, A.. 2008. Pengaruh Perilaku pengunjung terhadap Jumlah Kunjungan di Taman Wisata Alam Punti kayu Palembang. Jurnal penelitian Hutan dan Konservasi Alam. Vol. 5 (5); 423-433.

Purnomo, H.. 2013. Kajian Potensi dan Daya Dukung Ekowisata di Kawasan Cagar Alam Pulau Sempu. [Tesis]. SPS IPB, Bogor.

Purwanto, S.. 2014. Kajian Potensi dan Daya Dukung Taman Wisata Alam Bukit Kelam untuk Strategi Pengembangan Ekowisata. [Tesis]. SPS IPB, Bogor.

Sari, Y., Yuwono, S.B., Rusita. 2015. Analisis Potensi dan Daya Dukung Sepanjang Jalur Ekowisata Hutan Mangrove di Pantai Sari Ringgung, Kabupaten Pesawaran, Lampung. Jurnal Sylva Lestari. Vol. 3 (3): 31-40.

Sarjono, H., dan Julianita, W.. 2011. SPSS vs LISREL: Sebuah Pengantar, Aplikasi untuk Riset. Penerbit Salemba Empat, Jakarta.

Supriatna, J.. 2008. Melestarikan Alam Indonesia. Yayan Obor Indonesia, Jakarta.

Utari, W.D.. 2014. Daya Dukung Ekologis dan Psikologis Ekowisata di Kebun Raya Cibodas.

[Tesis]. SPS IPB, Bogor. 


\section{TABEL-TABEL}

Tabel 1. Karakteristik pengunjung EJP.

\begin{tabular}{|c|c|c|c|}
\hline & Variabel & Frekunsi & (\%) \\
\hline \multicolumn{4}{|c|}{ 1. Jenis Kelamin } \\
\hline & - Laki-laki & 23 & 38,3 \\
\hline & - Perempuan & 37 & 61,7 \\
\hline \multicolumn{4}{|c|}{ 2. Status Penikahan } \\
\hline & - Menikah & 13 & 21,7 \\
\hline & - Belum menikah & 47 & 78,3 \\
\hline \multicolumn{4}{|c|}{ 3. Kelompok Usia } \\
\hline & $-\quad 12-20$ tahun & 11 & 18,3 \\
\hline & - $\quad 21-30$ tahun & 39 & 65,0 \\
\hline & - $\quad 31-40$ tahun & 9 & 15,0 \\
\hline & $-\quad>40$ tahun & 1 & 1,7 \\
\hline \multicolumn{4}{|c|}{ 4. Asal } \\
\hline & - Dalam Negeri & 60 & 100,0 \\
\hline \multicolumn{4}{|c|}{ 5. Pendidikan } \\
\hline & - $\quad$ SLTA & 42 & 70,0 \\
\hline & - Diploma & 1 & 1,7 \\
\hline & - Sarjana & 9 & 15,0 \\
\hline & - Pascasarjana & 8 & 13,3 \\
\hline \multirow{7}{*}{6.} & Pekerjaan & & \\
\hline & - Mahasiswa & 42 & 71,7 \\
\hline & - $\quad$ Pegawai negeri sipil & 2 & 3,3 \\
\hline & - Pegawai swasta & 5 & 8,3 \\
\hline & - Wiraswasta & 2 & 3,3 \\
\hline & - Guru/Dosen & 6 & 10,0 \\
\hline & - Rohaniawan & 2 & 3,3 \\
\hline \multirow[t]{5}{*}{7.} & Pendapatan & & \\
\hline & - Tidak ada & 26 & 43,3 \\
\hline & $-\quad<1$ juta & 14 & 23,3 \\
\hline & $-1-3$ juta & 14 & 23,3 \\
\hline & $-\quad 3-5$ juta & 6 & 10,0 \\
\hline
\end{tabular}

Tabel 2. Karakteristik kunjungan yang dilakukan di EJP.

\begin{tabular}{llcc}
\hline \multicolumn{1}{c}{ Variabel } & Frekuensi & (\%) \\
\hline 1. & Bentuk kunjungan & & \\
- Teman & 2 & 3,3 \\
- Rombongan wisata & 57 & 95,0 \\
- Sekolah & 1 & 1,7 \\
2. Lama kunjungan & & \\
- < 2 jam & 6 & 10,0 \\
- 2-4 jam & 50 & 83,3 \\
- 4-6 jam & 4 & 6,7 \\
3. Frekuensi kunjungan & & \\
- Pertama kali & 54 & 90,0 \\
- 2 kali & 6 & 10,0
\end{tabular}

4. Pengeluaran kunjungan 
- Tidak ada

- $<200.000$

- 400.000-600.000

5. Informasi tentang EJP

- Internet

- Sosial media

- Teman/kolega

- Brosur/leaflet

Tabel 3. Penilaian terhadap komponen-komponen penyusun potensi ODTWA.

\begin{tabular}{|c|c|c|c|}
\hline \multirow[b]{2}{*}{ Komponen } & \multicolumn{3}{|c|}{ Nilai Potensi (\%) } \\
\hline & EJP & $\mathrm{PS}^{1}$ & $\mathrm{BK}^{2}$ \\
\hline Daya tarik obyek wisata & $43,8^{r}$ & $83,3^{t}$ & $89,6^{t}$ \\
\hline Aksebilitas & $88,2^{t}$ & $64,7^{\mathrm{s}}$ & $27,8^{r}$ \\
\hline Kondisi masyarakat sekitar & $79,2^{\mathrm{s}}$ & $83,3^{\mathrm{t}}$ & $75,0^{\mathrm{s}}$ \\
\hline Elemen institusi & $54,2^{r}$ & $50,0^{r}$ & $100,0^{t}$ \\
\hline Potensi pasar & $26,8^{r}$ & $97,4^{\mathrm{t}}$ & $38,4^{r}$ \\
\hline Akomodasi & $100,0^{t}$ & $33,3^{r}$ & $33,3^{r}$ \\
\hline Pengelolaan dan pelayanan & $77,8^{s}$ & $61,1^{\mathrm{s}}$ & $83,3^{t}$ \\
\hline Iklim & $58,3^{s}$ & $58,3^{\mathrm{s}}$ & $66,7^{\mathrm{s}}$ \\
\hline Keamanan & $50,0^{r}$ & - & $83,3^{t}$ \\
\hline Sarana dan prasarana wisata & $56,7^{\mathrm{s}}$ & $70,0^{\mathrm{s}}$ & $100,0^{t}$ \\
\hline Ketersediaan air bersih & $91,7^{t}$ & $60,0^{s}$ & $93,3^{t}$ \\
\hline Hubungan dengan obyek wisata di sekitarnya & $70,0^{t}$ & $90,0^{t}$ & $100,0^{t}$ \\
\hline Penurunan kualitas lingkungan & $66,7^{s}$ & $66,7^{\mathrm{s}}$ & $33,3^{r}$ \\
\hline Daya dukung kawasan & $80,0^{t}$ & $83,3^{t}$ & $76,7^{\mathrm{t}}$ \\
\hline \multirow[t]{2}{*}{ Pangsa pasar } & $88,9^{t}$ & $83.3^{\mathrm{t}}$ & $77,8^{\mathrm{s}}$ \\
\hline & sedang & sedang & sedang \\
\hline
\end{tabular}

Keterangan : ${ }^{1}$ Pulau Sempu (Purnomo, 2013); ${ }^{2}$ Bukit Kelam (Purwanto, 2014); ${ }^{\mathrm{r}}=$ rendah; ${ }^{\mathrm{s}}=$ sedang $;{ }^{\mathrm{t}}=$ tinggi.

\section{GAMBAR}

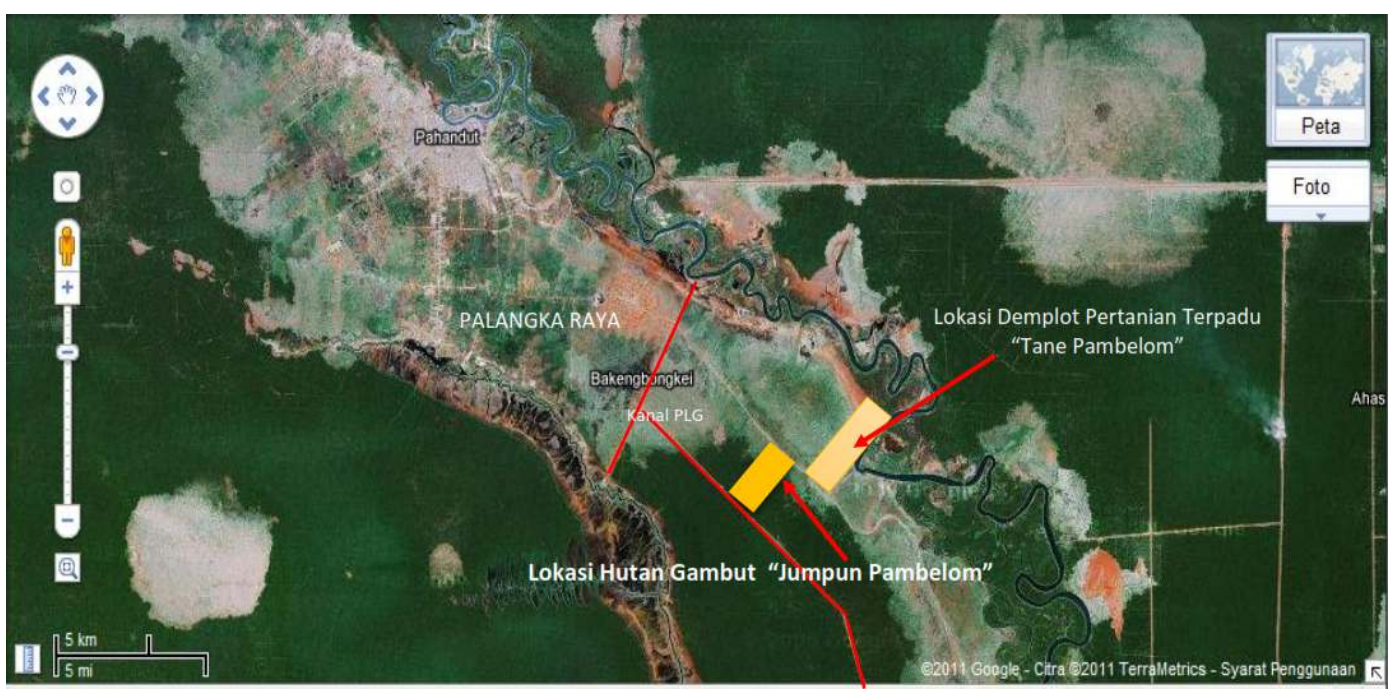

Gambar 1. Lokasi EJP. 
